\title{
Application of a real-time PCR assay to detect and quantify the myxozoan parasite Ceratomyxa shasta in river water samples
}

\author{
Sascha L. Hallett*, Jerri L. Bartholomew \\ Center for Fish Disease Research, Department of Microbiology, Oregon State University, Corvallis, Oregon 97331, USA
}

\begin{abstract}
Ceratomyxa shasta is a virulent pathogen of salmonid fishes that is enzootic in the Pacific Northwest of North America. Current parasite detection methods involve sentinel fish exposures that are laborious and time-consuming. As a substitute, a filtering protocol and a quantitative real-time TaqMan polymerase chain reaction (QPCR) assay were developed to detect and enumerate parasite spores in river water. Fluorescence was detected from both the myxospore and actinospore stages of the parasite but not from the fish or polychaete hosts or from 9 other myxozoans tested. Less than 1/1000th of a spore was detected, indicating each had $>1000$ copies of the target $18 \mathrm{~S}$ rRNA gene. The assay detected 1 spore in 11 river water. Inhibition of the assay by some river samples was overcome by reducing the template volume and including bovine serum albumin in the reaction; occasionally a second purification step was required. The QPCR methodology was utilised to investigate the temporal and spatial distribution of C. shasta in the Klamath River, Oregon/ California. The parasite was detected throughout the river, and 2 of 5 tributaries tested contributed parasites to the mainstem. Correlation of QPCR cycle threshold values with a standard curve for known starting numbers of whole spores revealed several sites where parasite abundance was in excess of 20 spores $1^{-1}$. Although QPCR data corroborated results of sentinel fish exposures, spore numbers did not correlate consistently with mortality in the exposure groups. The water sampling and filtering protocol combined with the QPCR assay is a simple and relatively rapid method for detection and quantification of parasite levels in environmental water samples.
\end{abstract}

KEY WORDS: Ceratomyxa shasta - TaqMan · Klamath River · PCR · Myxozoa · Real-time PCR · River water · QPCR · Parasite quantification

Resale or republication not permitted without written consent of the publisher

\section{INTRODUCTION}

The freshwater myxozoan parasite Ceratomyxa shasta causes a serious disease among species of the family Salmonidae in the Pacific Northwest of North America (Palenzuela et al. 1999). The parasite has a 2host life cycle with development in both a fish and a polychaete (Manayunkia speciosa) (Bartholomew et al. 1997). The infective stage for fish is a tetractinomyxon actinospore $14 \times 11 \mu \mathrm{m}$ in size whereas the infective stage for the polychaete is a ceratomyxa myxospore 14 to $23 \mu \mathrm{m}$ long $\times 6$ to $8 \mu \mathrm{m}$ wide (Bartholomew et al. 1997) (Fig. 1). In its fish hosts, C. shasta proliferates in the intestinal tract and causes a severe inflammatory response, tissue necrosis and consequent mortality (Bartholomew et al. 1989b).

Traditionally, sentinel exposures (naïve fish of a known susceptible strain held in cages) have been the sole means to detect the parasite in a given waterway. Diagnosis is then either by detection of parasite DNA using a specific polymerase chain reaction (PCR) assay (as early as 10 to $14 \mathrm{~d}$ post-exposure), visual detection of mature spores in intestinal scrapings (may take up to $90 \mathrm{~d}$ to obtain data), or examination of histological sections using monoclonal antibodies and fluorescein or enzyme-conjugated secondary antibodies (Bartholomew et al. 1989a, 2004, Palenzuela et al. 1999, Fox et al. 2000). Development of a real-time (or quantitative) 

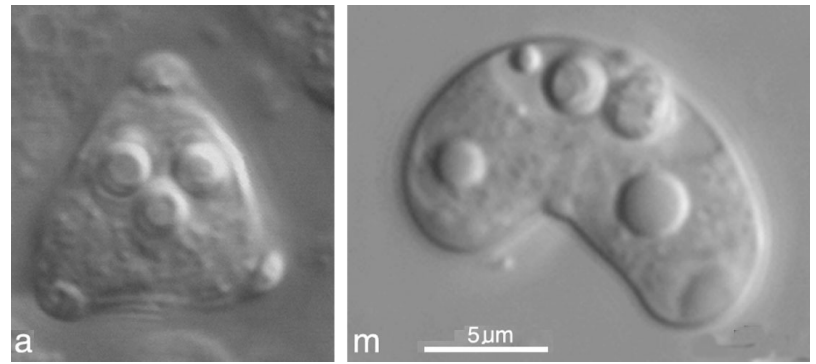

Fig. 1. Ceratomyxa shasta. Photomicrographs of (a) actinospore (stage that develops in annelid host that is infective for fish host) and (m) myxospore (stage that develops in fish host that is infective for annelid host). Fresh, unstained material, under coverslip; Nomarski interference contrast

PCR (QPCR) for direct assessment of the parasite in water samples could replace these more labour intensive, expensive and time consuming techniques and eliminate the use of live fish.

QPCR has been utilised previously to detect human and animal pathogens in environmental water samples, including yeast cells, dinoflagellates, astroviruses and Cryptosporidium parvum (Bowers et al. 2000, Brinkman et al. 2003, Fontaine \& Guillot 2003, Le Cann et al. 2004), and appears to be an appropriate means by which to detect myxozoan spores. The assay differs from standard PCR by using fluorescence to track PCR products of a target DNA sequence during cycling. This allows quantitation, as the increase in fluorescence is proportional to the amount of accumulated PCR product. The assay is made more specific by the inclusion of a sequence-specific dual-labelled fluorescent probe in the PCR mix. Fluorescence is detected only if both the probe anneals to the target sequence and amplification of the target occurs. QPCR eliminates the need for post-PCR visualisation of products in gels and is a rapid, sensitive as well as specific method for the detection of target DNA.

Our goals in this study were to develop a QPCR assay specific for Ceratomyxa shasta, and a protocol to detect and enumerate parasite spores in river water samples. Samples for testing these methods were collected as part of a study of the Klamath River, which straddles southern Oregon and northern California. In this river, C. shasta is enzootic (Hendrickson et al. 1989), and infection rates of up to $100 \%$ in juvenile Chinook salmon Oncorhynchus tshawytscha exposed for $4 \mathrm{~d}$ have been recorded (Foott et al. 2003). We used the new QPCR approach, which incorporates a sampling and filtering protocol, concurrently with sentinel fish exposures (Stocking et al. 2006) to investigate the temporal and spatial distribution of C. shasta in the Klamath River and identify sites of high abundance and tributaries that contribute spores to the mainstem river.

\section{MATERIALS AND METHODS}

Collection and filtration of river water samples. We experimented with a variety of filtration methods. These included trialling different volumes of river water and different $5 \mu \mathrm{m}$ filters including Nitex mesh (CellMicroSieves, Biodesign), Poretics polycarbonate membranes (GE Osmonics) and MF disc mixed cellulose ester membranes (Millipore). The cellulose membrane was selected as it clogged less readily than the polycarbonate equivalent. The final protocol was as follows:

Water samples were collected from approximately $30 \mathrm{~cm}$ below the water surface in a 21 plastic bottle and kept cool until processing (within $24 \mathrm{~h}$ of collection). Each bottle was gently inverted several times and its contents divided into $4 \times 500 \mathrm{ml}$ glass flasks. The water was allowed to stand for several minutes to allow particulate matter to settle, then poured into the filtration apparatus comprised of a glass funnel clamped onto a fritted glass support inserted into a 21 side arm flask connected to a vacuum pump. The sample was filtered (400 $\mathrm{mm} \mathrm{Hg}$ pressure) through a MF-Millipore filter membrane ( $5 \mu \mathrm{m}$ pore size, $47 \mathrm{~mm}$ diameter, MF disc hydrophilic mixed cellulose esters) placed on the glass support. Samples with limited particulate matter were filtered in pairs (1 l per filter membrane). Turbid samples were filtered using only $500 \mathrm{ml}$ per filter membrane. Each flask was rinsed several times with nanopure water and the rinse water was added to the filter. The funnel was rinsed also, and once all liquid had passed through, it was unclamped, and the base wiped. The filter membrane was folded in half 4 times, using Millipore flat forceps, and placed inside a $2.0 \mathrm{ml}$ microcentrifuge tube and frozen.

DNA extraction. DNA was extracted using a QIAGEN DNeasy Tissue Kit (protocol for animal tissues) with several modifications. The folded filter membrane was first cut into strips ( $2 \mathrm{~mm}$ wide) to promote contact of its contents with buffer and Proteinase K. Scissors and forceps were wiped between samples from different sites. Samples were lysed in $360 \mu \mathrm{l}$ buffer ATL to immerse the entire filter. Since all samples were greater than $750 \mu$ l they were applied to the QIAGEN column in at least 2 steps with centrifugation. Any samples which had been filtered as $2 \times 500 \mathrm{ml}$ per filter membrane were combined at this point (i.e. the contents from both lysed filter membranes were applied to a single column). Purified DNA was eluted in 3 steps of 50, 50 and $20 \mu l$ molecular grade water (MG water; Eppendorf) to maximise the final yield, and then stored at $-20^{\circ} \mathrm{C}$.

DNA was also extracted from a range of controls, including infected fish tissue, myxospores isolated from infected fish and actinospores isolated from 
infected polychaetes. These were placed in microcentrifuge tubes and frozen prior to DNA extraction using the standard DNeasy protocol for animal tissues. Tissue samples were eluted in 1 step of $100 \mu$ buffer AE, whereas spore samples were eluted as described for water samples.

Primer design. The primers and probe were selected using Primer Express Version 2.0.0 software (Applied Biosystems). A combination specific to the 18S rDNA sequence of Ceratomyxa shasta (GenBank Accession No. AF001579) was designed after reference to the host/parasite alignment of 18S rDNA sequences of Bartholomew et al. (1997), as well as additional myxozoan sequences available in GenBank (including the only other 2 sequenced Ceratomyxa species, C. labracis [AF411472] and C. sparusaurati [AF411471]), and with consideration of the C. shasta specific primers developed by Palenzuela et al. (1999). The forward primer (Cs-1034F 5' CCA GCT TGA GAT TAG CTC GGT AA) begins at Base Position 1034, the TaqMan TAMRA probe (CsProbe-1058T 6FAMCGA GCC AAG TTG GTC TCT CCG TGA AAA CTAMRA) at Position 1058, and the reverse primer (Cs-1104R CCC CGG AAC CCG AAA G) at Position 1104. This combination generates a 71 bp amplicon. A nucleotide-nucleotide BLAST search in GenBank (Altschul et al. 1997) using each oligonucleotide sequence indicated no identity with any other myxozoans, potential host group or other organisms potentially found in water samples.

QPCR. The optimal combination of primer and probe concentrations was determined according to the TaqMan Universal PCR Master Mix protocol guidelines (Applied Biosystems). A $20 \mu \mathrm{l}$ reaction volume was used, and comprised $800 \mathrm{nM}$ of each primer (Applied Biosystems), $200 \mathrm{nM}$ probe (Applied Biosystems), $10 \mu \mathrm{l}$ TaqMan Universal PCR Master Mix (contains AmpliTaq gold DNA polymerase, AmpErase UNG, dNTPs with dUTP, passive reference and optimised buffer components) (Applied Biosystems), and up to $6 \mu \mathrm{l}$ DNA template or MG water. Reactions were performed in an ABI PRISM 7000 sequence detection system in either ABI PRISM ${ }^{\mathrm{TM}}$ optical tubes or MicroAmp ${ }^{\circledR}$ optical 96well reaction plates with the following thermal cycling conditions: initial $2 \mathrm{~min} 50^{\circ} \mathrm{C}$ step for optimal UNG enzyme activity, $10 \mathrm{~min} 95^{\circ} \mathrm{C}$ step to activate AmpliTaq gold enzyme, followed by 40 to 50 cycles of denaturation at $95^{\circ} \mathrm{C}$ for $15 \mathrm{~s}$ and annealing/extension at $60^{\circ} \mathrm{C}$ for $1 \mathrm{~min}$. Samples were represented in triplicate and both a positive control (parasite DNA) and a negative control (non-template $=$ MG water) were included in each reaction run. Reactions with environmental water included $0.5 \mu \mathrm{l}$ stock BSA (bovine serum albumin, 10 $\mathrm{mg} \mathrm{ml}^{-1}$; final concentration of $250 \mathrm{ng}^{-1} \mathrm{l}^{-1}$ New England Biolabs) and used $1 \mu$ l of the DNA template (refer to 'Results; Inhibition of QPCR').
Specificity. The assay was tested on other myxozoans including Myxobolus cerebralis, $M$. insidiosus, $M$. squamalis, Parvicapsula minibicornis, Henneguya salmonicola, Chloromyxum auratum, Myxobolus spp. and, Myxidium sp., as well as salmonid and polychaete hosts.

Sensitivity. The sensitivity of the assay was evaluated using DNA derived from a range of sources: whole un-extracted spores, extracted spores, extracted spores on filter paper and infected fish tissue.

The cycle threshold $(\mathrm{Ct})$ for a single myxospore was determined from individual spores placed using a fine glass pipette directly into QPCR tubes and air-dried overnight before addition of the QPCR mix. The approximate loss of DNA incurred through the extraction process was gauged by air-drying known numbers of myxospores (replicates of 1, 2, 4, 5, 10, 20 and 25) on pieces of glass microscope coverslips which were placed inside microcentrifuge tubes. Additionally, myxospores (replicates of 1 and 10) and actinospores (replicates of 1, 5, 10 and 20) were pipetted onto filter membranes moistened with MG water and processed as per the environmental water samples.

We performed 10-fold serial dilutions of known starting numbers of myxospores (5,10 and 25) representing from 1.25 to $1.25 \times 10^{-5}$ spores per reaction and of synthetic template of the $71 \mathrm{bp}$ target region (Invitrogen) ranging from $10^{12}$ copies ( $34 \mathrm{ng}$ ) to 1 copy per reaction to determine the minimum detection level of the assay. Sample dilution series were prepared following ABI guidelines (real-time compendium: 5700 SDS Version 4.0). The initial starting number of template copies was calculated using the data provided by Invitrogen: amount/mol wt $\times$ Avogadro's number. A subset of DNA concentrations was measured using a NanoDrop ND1000 Spectrophotometer (NanoDrop Technologies).

The copy number of $18 \mathrm{~S}$ rRNA genes per spore was approximated by comparison of $\mathrm{Ct}$ values for individual un-extracted spores with serial dilutions of known quantities of the target amplicon (derived from extracted spores and synthetic template). Standard curves were generated both from known concentrations and copy numbers of the synthetic template as well as from known starting numbers of whole spores. The amplification efficiency $(E)$ was estimated by the formula $E=10^{-1 / s}-1$, where $s$ is the slope of the standard curve (Fontaine \& Guillot 2003). Samples were re-assayed on different occasions to assess reproducibility of the assay.

Inhibition of QPCR. Addition of BSA (20 to $250 \mathrm{ng}$ $\mathrm{\mu l}^{-1}$ ) in the QPCR mix (Bowers et al. 2000, Brinkman et al. 2003) has been found to reduce inhibition (Guy et al. 2003), as has dilution of the extracted sample DNA (see Brinkman et al. 2003). We tested different concentrations of BSA to determine the optimum amount required to suppress inhibition. We also experimented with the volume of extracted sample used in a reaction 
to balance the amount of inhibition and the ability to detect 1 spore in 11 river water. To determine whether the river water inhibited amplification and/or the fluorescence part of the QPCR, the QPCR products were electrophoresed with a $50 \mathrm{bp}$ ladder on a $2 \% 1 \times \mathrm{TAE}$ agarose gel with $1 \%$ ethidium bromide.

To assess inhibition in samples collected at the various sites along the Klamath River and to ascertain whether negative samples were actually spore free or highly inhibited, extracted river samples were spiked with Ceratomyxa shasta DNA and included in each assay and compared with spiked MG water. Spiked samples with a higher $\mathrm{Ct}$ value than the spiked MG water were considered inhibited. We re-purified $60 \mu \mathrm{l}$ of each of these samples using a QIAquick PCR purification kit (QIAGEN) and re-eluted the DNA in $60 \mu \mathrm{l}$ water (3 elutions of $20 \mu$ to maximise yield) and re-ran the samples (spiked and unspiked). A sample not exhibiting inhibition was included for comparison.

Field sampling. In June 2004, river water was sampled concurrently with sentinel fish exposures at 19 sites along the Klamath River (Oregon/California, USA), including lakes, reservoirs and tributaries, to assess spatial prevalence of Ceratomyха shasta (Fig. 2) (see Stocking et al. 2006). Each sample site was represented by $2 \times 11$ samples. Samples were obtained from 12 sites above Iron Gate Reservoir (Fig. 2) on 18 June in co-ordination with the setting out of sentinel cages and from 7 sites below the dam on 22 June in co-ordi- nation with the retrieval of the sentinel cages at the end of the $4 \mathrm{~d}$ exposure period. At 2 sites, Bypass Reach (J. C. Boyle), and Beaver Creek (Fig. 2), water samples were taken at $2 \mathrm{~h}$ intervals throughout the day (6 samples on 19 June and 9 samples on 21 June, respectively) to assess temporal variation in parasite prevalence. Temperature and dissolved oxygen were recorded with a YSI meter (Model 55, Yellow Springs) and relative changes in water level were noted.

\section{RESULTS}

\section{Specificity}

The Primer Express software generated 200 combinations of primers and probes which were variants of 5 main amplicons. These were aligned with other myxozoans and the most Ceratomyxa shasta-specific combination was selected. A BLAST search using the selected forward primer scored zero hits and the probe and the reverse primer partially hit several non-myxozoan and non-host species, members of which were unique, i.e. none represented/appeared in both searches. Neither non- $C$. shasta myxozoan samples nor host samples fluoresced.

Visualisation of QPCR products on an agarose gel confirmed amplification of a single template of the expected size.

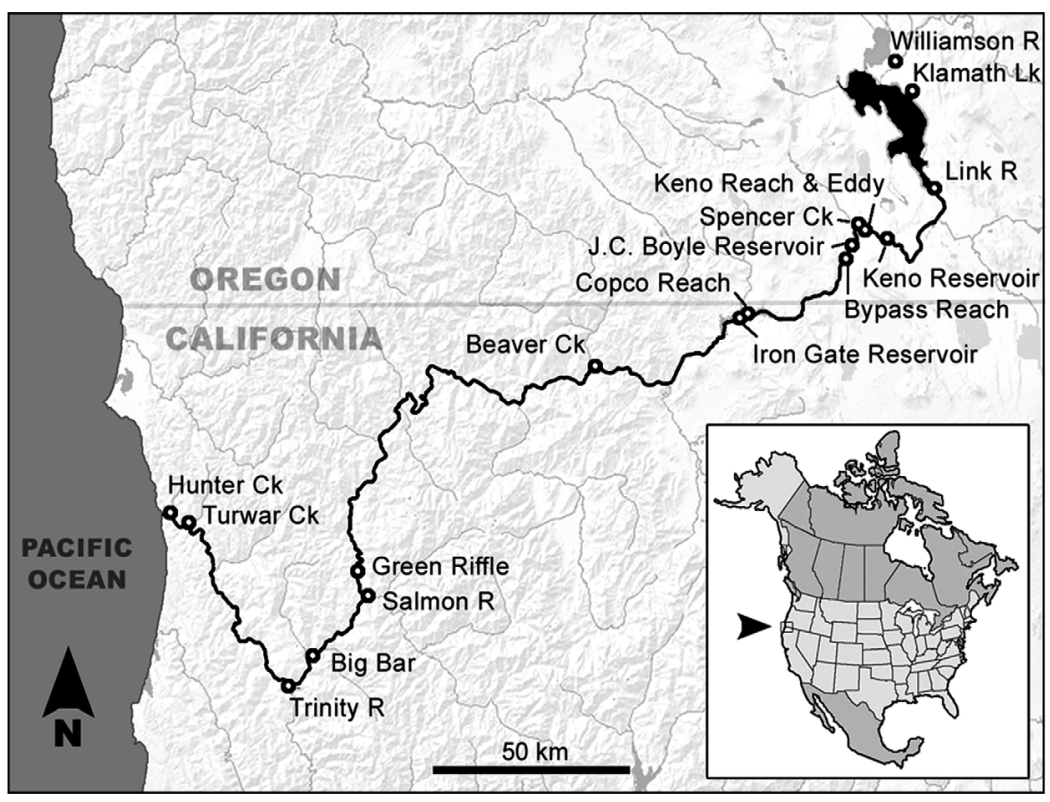

Fig. 2. Klamath River in southern Oregon/northern California, USA, showing sites of sentinel fish exposures and water sampling. Keno Reach \& Eddy comprised 2 nearby but separate sites, and there were also 2 sites at Spencer Creek (Spencer Creek proper and a site further upstream). Inset: site area in context of North America

\section{Sensitivity}

The Ct values for different sources of parasite DNA are presented in Table 1 and are inversely proportional to the quantity of DNA present. The higher $\mathrm{Ct}$ value (an average 4.1 cycles) of extracted versus un-extracted spores indicates a loss of DNA during the extraction process. The necessary inclusion of a filter membrane in the protocol led to further loss of DNA.

DNA in serial dilutions of extracted myxospores was detectable down to $2.5-5.0 \times 10^{-4}$ of a spore, indicating that each spore had a minimum of 2000 to 4000 copies of 18S rDNA (data not shown, but was derived from values common to the ranges of detection for each of the 5, 10 and 25 spore samples). DNA in serial dilutions of the synthetic 71 bp template was detectable down to 100 copies, or approximately 3 ag (Fig. 3). Thus if the minimum detection 
Table 1. Ceratomyxa shasta. Cycle threshold (Ct) values for spores processed by different methods. $\mathrm{n}=$ number of samples. Reactions for each extracted sample were performed in triplicate

\begin{tabular}{|c|c|}
\hline Sample type & Ct value \\
\hline $\begin{array}{l}1 \text { myxospore, un-extracted } \\
\text { (1 spore placed directly into QPCR tube) }\end{array}$ & $25.1-27.9(\mathrm{n}=9 ;$ avg. 26.8$)$ \\
\hline $\begin{array}{l}1 \text { myxospore, extracted DNA equivalent } \\
(6 \mu \mathrm{l} \text { of } 20 \text { extracted spores eluted into } 120 \mu \mathrm{l})\end{array}$ & $30.5-32.5(\mathrm{n}=1 ; \operatorname{avg} .31 .4)$ \\
\hline $\begin{array}{l}1 \text { myxospore, extracted } \\
(1 \mu \mathrm{l} \text { of } 1 \text { extracted spore eluted into } 120 \mu \mathrm{l})\end{array}$ & $30.3-35.0(\mathrm{n}=3 ; \operatorname{avg} .32 .7)$ \\
\hline $\begin{array}{l}1 \text { myxospore, extracted with filter paper } \\
(1 \mu \mathrm{l} \text { of } 1 \text { extracted spore eluted into } 120 \mu \mathrm{l})\end{array}$ & $35.2-37.1(\mathrm{n}=2 ; \operatorname{avg} .36 .2)$ \\
\hline $\begin{array}{l}1 \text { actinospore, extracted with filter paper } \\
(1 \mu \mathrm{l} \text { of } 1 \text { extracted spore eluted into } 120 \mu \mathrm{l})\end{array}$ & $33.5-35.3(\mathrm{n}=2 ; \operatorname{avg} .34 .6)$ \\
\hline $\begin{array}{l}10 \text { myxospores, extracted with filter paper } \\
(1 \mu \mathrm{l} \text { of } 10 \text { extracted spores eluted into } 120 \mu \mathrm{l})\end{array}$ & $30.8-32.7(n=2 ; \operatorname{avg} .31 .8)$ \\
\hline $\begin{array}{l}10 \text { actinospores, extracted with filter paper } \\
(1 \mu \mathrm{l} \text { of } 10 \text { extracted spores eluted into } 120 \mu \mathrm{l})\end{array}$ & $29.9-31.5(\mathrm{n}=3 ;$ avg. 30.6) \\
\hline
\end{tabular}

curve for known starting numbers of whole spores ranging from 1 spore (avg. Ct 34.6 for the actinospore) to 20 spores (avg. Ct 29.4 for the actinospore), which were processed and assayed as per river water samples, had a slope of -4.0166 with an $\mathrm{R}^{2}$ of 0.931 (Fig. 4). Amplification efficiency was estimated to be $77 \%$. Ct values were reproducible across different reactions.

\section{Inhibition of QPCR}

Comparison of river water samples with MG water, both spiked with parasite DNA, presented a range in inhibition of the QPCR from none to complete (at reaction volumes of 1.0 to $4.6 \mu \mathrm{l}$ of $120 \mu \mathrm{l}$ extracted DNA from 11 starting volume). Incorporation of a filter mem-

level is 100 copies and this corresponds to 2.5-5.0 $\times$ $10^{-4}$ of a spore, then each myxospore theoretically contains 4 to $8 \times 10^{5}$ copies. This was further supported by correlation of the $\mathrm{Ct}$ value of a whole, un-extracted, single spore with that of synthetic $71 \mathrm{bp}$ template which corresponded to $1 \times 10^{5}$ copies.

Standard curves were generated using both the synthetic template and from known starting numbers of spores; 10 -fold serial dilutions of the synthetic template were linear over 9 orders of magnitude from $10^{11}$ copies (avg. Ct 5.0) down to $10^{2}$ copies (avg. Ct 40.1); the slope of the curve was -3.8121 , with a squared correlation coefficient $\left(\mathrm{R}^{2}\right)$ of 0.993 (Fig. 3). Amplification efficiency was estimated to be $83 \%$. The standard

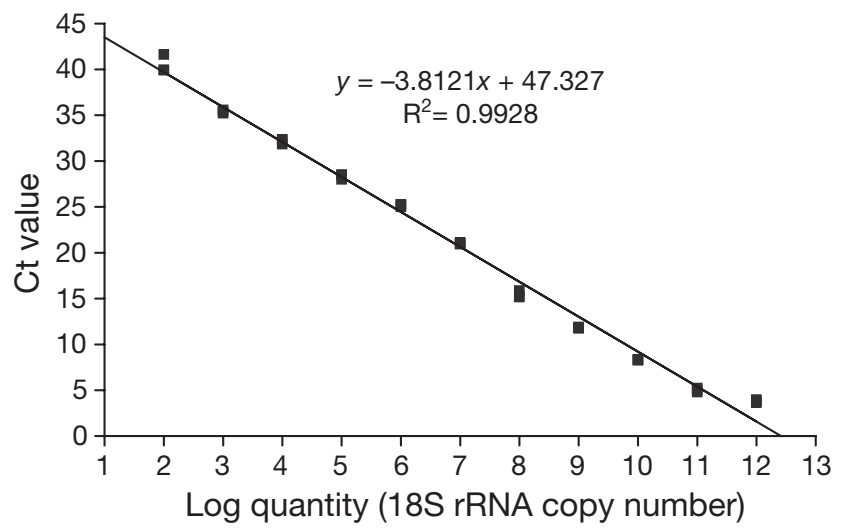

Fig. 3. Ceratomyxa shasta. Standard curve derived from 10 -fold serial dilutions of synthetic 18S rDNA template, showing log of $18 \mathrm{~S}$ rRNA copy number versus QPCR cycle threshold $(\mathrm{Ct})$ value. Reactions for each dilution were performed in triplicate. Curve is linear over 9 orders of magnitude from $10^{2}$ to $10^{11}$ copies or 3 ag to $3 \mathrm{ng}$ brane in the processing of water samples enabled thorough rinsing and reduced inhibition: comparison of spiked 11 samples differed by 3 cycles.

Addition of BSA reduced but did not eliminate inhibition: $20 \mathrm{ng}^{-1} \mathrm{l}^{-1}$ enabled parasite DNA to be detected in $1 \mu \mathrm{l}$ sample volumes (Table 2); at higher sample volumes, parasite DNA could not be detected. Increasing BSA concentration to $250 \mathrm{ng} \mathrm{\mu l}^{-1}$ improved amplification

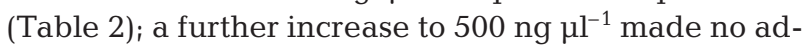
ditional improvement (data not shown). Thus $250 \mathrm{ng}^{-1} \mathrm{l}^{-1}$ of BSA per reaction was included in all subsequent reactions involving environmental water samples. Comparison of MG water samples with and without BSA showed no difference in $\mathrm{Ct}$ values. Visualisation of the

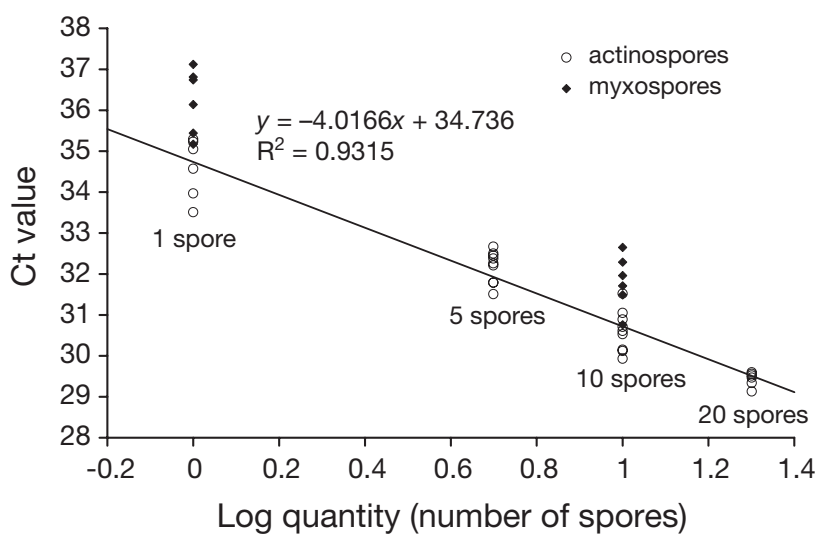

Fig. 4. Ceratomyxa shasta. Standard curve derived from known numbers of spores pipetted onto filter paper and extracted as per river water samples, showing log of number of spores versus QPCR Ct value. Each spore number was represented by 2 to 3 replicates and reactions for each were performed in triplicate 
Table 2. Inhibition of QPCR: comparison of different template volumes of river water (1 l processed and eluted in $120 \mu \mathrm{l}$ ) and molecular grade (MG) water spiked with Ceratomyxa shasta DNA and including BSA. ud = undetected within 40 cycles. Ct: cycle threshold

\begin{tabular}{|c|c|c|c|}
\hline Water sample & $\begin{array}{l}\text { Volume }(\mu \mathrm{l}) \text { in } \\
20 \mu \mathrm{l} \text { reaction }\end{array}$ & $\begin{array}{c}\mathrm{BSA} \\
\left({\left.\mathrm{ng} \mu \mathrm{l}^{-1}\right)}\right.\end{array}$ & $\begin{array}{c}\text { Avg. } \\
\text { Ct value }\end{array}$ \\
\hline River $+1 \mu$ spike & $\begin{array}{l}4.6 \\
4.6 \\
4.5\end{array}$ & $\begin{array}{c}0 \\
20 \\
250\end{array}$ & $\begin{array}{l}\text { ud } \\
\text { ud } \\
\text { ud }\end{array}$ \\
\hline $\mathrm{MG}+1 \mu \mathrm{l}$ spike & $\begin{array}{l}4.6 \\
4.6 \\
4.5\end{array}$ & $\begin{array}{c}0 \\
20 \\
250\end{array}$ & $\begin{array}{l}18.6 \\
18.6 \\
19.8\end{array}$ \\
\hline River $+0.2 \mu$ l spike & $\begin{array}{l}1.0 \\
1.0 \\
1.0\end{array}$ & $\begin{array}{c}0 \\
20 \\
250\end{array}$ & $\begin{array}{c}\text { ud } \\
37.2 \\
25.6\end{array}$ \\
\hline $\mathrm{MG}+0.2 \mu \mathrm{l}$ spike & $\begin{array}{l}1.0 \\
1.0 \\
1.0\end{array}$ & $\begin{array}{c}0 \\
20 \\
250\end{array}$ & $\begin{array}{l}20.3 \\
19.9 \\
21.4\end{array}$ \\
\hline
\end{tabular}

QPCR products on a gel did not reveal an amplicon for the non-BSA river water samples, indicating disruption of the amplification process.

Reduction of the volume of the river sample used in a reaction from 4.6 to $1 \mu \mathrm{l}$ reduced inhibition in the presence of BSA (Table 2). Since $1 \mu \mathrm{l}$ was also determined to be sufficient to detect a single spore in a 11 sample, a volume of $1 \mu \mathrm{l}$ for environmental water samples was used in subsequent reactions.

Comparison of $\mathrm{Ct}$ values between spiked river samples and spiked MG water demonstrated that 5 Klamath River samples inhibited the QPCR: those collected from Keno Eddy, Keno Reach, Spencer Creek, Upstream of Spencer Creek and J. C. Boyle Reservoir (see Fig. 2). Re-purification of these samples successfully reduced or eliminated inhibition. Comparison of $\mathrm{Ct}$ values for the reference sample (Boyle Bypass Reach; no inhibition in original assays) indicated little loss of DNA during re-purification.

\section{Environmental water samples}

\section{Spatial prevalence}

The majority of the 19 sites sampled along the Klamath River tested positive for Ceratomyxa shasta DNA (Table 3). $\mathrm{Ct}$ values were generally consistent between the $2 \times 11$ subsamples from each site. Parasite levels fluctuated along the river mainstem. All mainstem sites, with the exception of Keno Reservoir, were positive. Only 1 of the 2 subsamples from Klamath Lake was positive and Klamath upstream of Spencer Creek showed very low parasite levels (both subsamples, Ct $>47$ ). The highest parasite concentrations were detected from the Klamath mainstem upstream of Beaver Creek (Ct 29) closely followed by the Williamson River (Ct 30). Comparison of the Ct of these sites with the standard curve of known starting numbers of spores (processed similarly, Fig. 4) indicates that these river samples contained in excess of 20 spores $1^{-1}$.

There were 2 tributaries, Williamson River and Hunter Creek, that contributed parasites to the main river. Trinity River had very low numbers of parasite present (only 1 of the 2 samples had a detectable $\mathrm{Ct}$ value [45]), and both Spencer Creek and Salmon River were negative for Ceratomyxa shasta. Negative river water samples spiked with C. shasta DNA registered a Ct value similar to that of MG water, indicating that the lack of fluorescence was due to the absence of $C$. shasta spores rather than the presence of inhibitors.
Table 3. Ceratomyxa shasta. Relative abundance at 19 sites along Klamath River and its tributaries $\left({ }^{*}\right)$ indicated by QPCR cycle threshold $(\mathrm{Ct})$ values for river water samples and mortalities for sentinel fish exposures. PCR detection in sentinel studies means parasite was detected in fish tissue samples by regular PCR. Sites grouped by sentinel data. Note that $\mathrm{Ct}$ values are inversely proportional to spore abundance. Avg. Ct values = initial (values for $2 \times 1 \mathrm{l}$ samples at each site) and adjusted (values adjusted for inhibition); ud = undetermined (no Ct value registered within 50 cycles)

\begin{tabular}{|c|c|c|c|}
\hline \multirow{2}{*}{$\begin{array}{l}\text { Sentinel fish exposure data } \\
\text { River Site }\end{array}$} & \multicolumn{2}{|c|}{ Avg. values } & \multirow{2}{*}{$\begin{array}{l}\text { Approx. } \\
\text { spores } 1^{-1}\end{array}$} \\
\hline & Initial & Adjusted & \\
\hline \multicolumn{4}{|l|}{ No mortalities, no PCR detection } \\
\hline Spencer Creek* & ud, ud & ud & 0 \\
\hline Salmon River* & ud, ud & ud & 0 \\
\hline Trinity River* & $45.0, \mathrm{ud}$ & $45+$ & $<1$ \\
\hline \multicolumn{4}{|l|}{ No mortalities, PCR detection } \\
\hline Keno Reservoir & ud, ud & ud & 0 \\
\hline J. C. Boyle Reservoir & $48.6,43.1$ & 38 & $<1$ \\
\hline Copco Reach & $39.2,38.4$ & 38 & $<1$ \\
\hline Hunter Creek* & $35.7,34.2$ & 35 & $<5$ \\
\hline \multicolumn{4}{|l|}{ Mortalities $<10 \%$, PCR detection } \\
\hline Klamath Lake & 39.0, ud & $39+$ & $<1$ \\
\hline Link River & $37.4,41.0$ & 39 & $<1$ \\
\hline Keno Reach & $37.7,36.5$ & 34 & $<5$ \\
\hline Keno Eddy & $38.6,38.8$ & 35 & $<5$ \\
\hline Upstream of Spencer Creek & $48.8,47.6$ & 41 & $<1$ \\
\hline Bypass Reach (J. C. Boyle) & $32.5,33.3$ & 32 & $>5<10$ \\
\hline Iron Gate Reservoir & $39.4,37.8$ & 38 & $<1$ \\
\hline \multicolumn{4}{|l|}{ Mortalities $>90 \%$, PCR detection } \\
\hline Upstream of Beaver Creek & $29.6,29.2$ & 29 & $>20$ \\
\hline Green Riffle (upstream of Salmon River) & $31.9,33.0$ & 32 & $>5<10$ \\
\hline Big Bar (upstream of Trinity River) & $34.0,33.2$ & 33 & $<5$ \\
\hline Upstream of Turwar Creek & $35.7,36.6$ & 36 & $<5$ \\
\hline Williamson River*,a & $30.8,30.7$ & 30 & $>10<20$ \\
\hline
\end{tabular}


Temporal prevalence

We took 6 water samples every $2 \mathrm{~h}$ over a $10 \mathrm{~h}$ period from 10:10 until 20:10 $\mathrm{h}$ on a single day at Bypass Reach. A temporal pattern was evident, even over this partial time period (Fig. 5A). Spore quantity increased over 10-fold (2.5 to $3 \mathrm{Ct}$ units; maximum range 4.17 units) over the $6 \mathrm{~h}$ period from 10:10 until 16:10 h, and then decreased until 20:10 h. This directly corresponded with water temperature, which also increased from start of sampling $\left(13.8^{\circ} \mathrm{C}\right)$ until $16: 10 \mathrm{~h}\left(15.6^{\circ} \mathrm{C}\right)$ and then decreased thereafter. The highest spore count corresponded with the highest temperature recorded as well as with the first distinct drop in river water level $(\sim 30 \mathrm{~cm})$ at 16:10 h. Although the water level continued to drop by another $\sim 30 \mathrm{~cm}$ over the next $2 \mathrm{~h}$, spore abundance began to decline.

In contrast, spore counts from the 9 samples taken at $2 \mathrm{~h}$ intervals over a $16 \mathrm{~h}$ period from 06:30 until $22.30 \mathrm{~h}$ upstream of Beaver Creek had no temporal relationship, and exhibited less variation than Boyle Bypass; a maximum difference in $\mathrm{Ct}$ of 2.71 was recorded between any 2 sample replicates $(<10$-fold difference) (Fig. 5B). There was no apparent change in water level during the sampling period. The temperature differ-
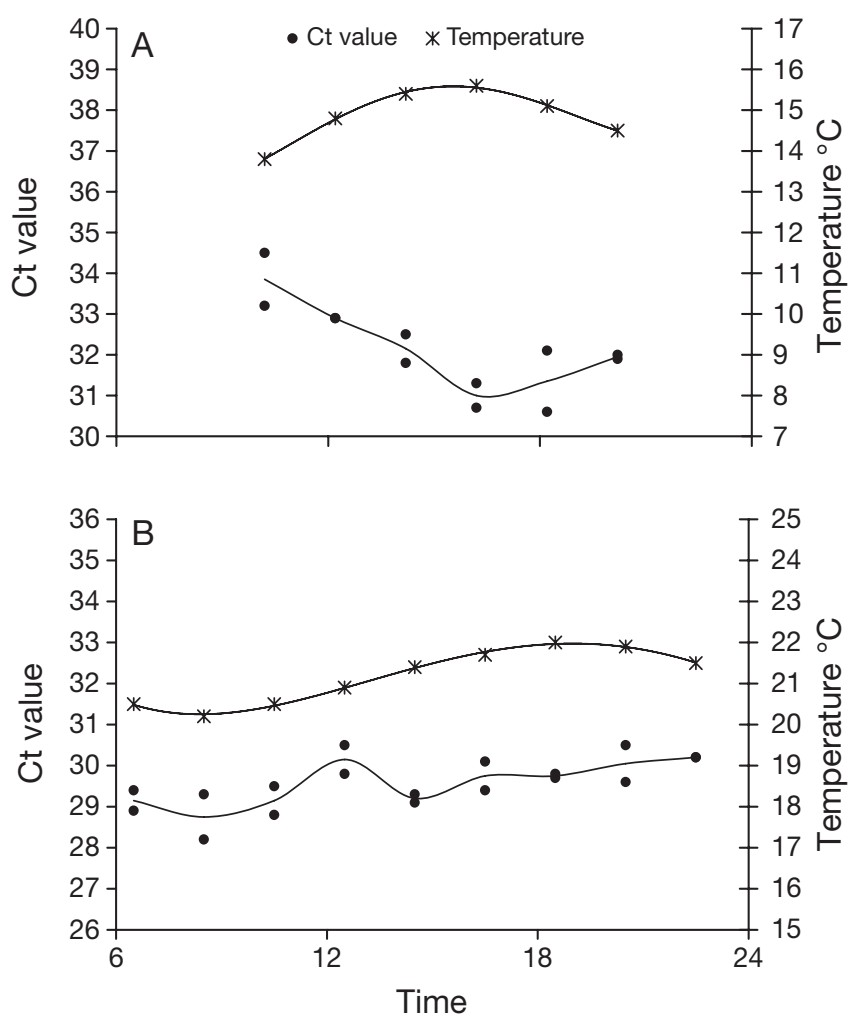

Fig. 5. Ceratomyxa shasta. Temporal abundance in Klamath River upstream of (A) Bypass Reach (J. C. Boyle) and (B) Beaver Creek. Two $1 \mathrm{l}$ water samples were taken at $2 \mathrm{~h}$ intervals over (A) $10 \mathrm{~h}$ and (B) $16 \mathrm{~h}$ ence recorded over the sampling period was equivalent for the 2 collection sites $\left(1.8^{\circ} \mathrm{C}\right)$.

Comparison of the water sample data with that of the sentinel exposure studies (Stocking et al. 2006) showed that the 2 data sets were generally consistent regarding presence of the parasite. Levels of prevalence and mortality in the fish, however, were not always directly proportional to the number of spores detected in the river water samples (Table 3). At 1 site (Trinity River), we detected very low numbers of spores but no fish held there became infected. At another site (Keno Reservoir), a low percentage of fish became infected but we did not detect spores.

\section{DISCUSSION}

Diagnosis of myxozoan infections is complicated by the variable morphology of presporogonic stages of the parasite in both hosts. A PCR diagnostic assay for Ceratomyxa shasta developed by Palenzuela et al. (1999) to detect the parasite in fish tissue samples has proven to be an invaluable tool for the monitoring of early and/or subclinical infections in both the fish and polychaete hosts. However, detection of waterborne $C$. shasta stages (myxospore and actinospore) is problematic and still relies on using fish as biological sensors. Herein we have described the development of a filtration protocol and QPCR test for detection of C. shasta in environmental water samples. This enabled us to investigate the relative abundance of the parasite over $423 \mathrm{~km}$ in the Klamath River (southern Oregon/northern California, USA) where the parasite impacts local salmonid populations (Hendrickson et al. 1989, Stocking et al. 2006).

Development of the QPCR initially utilised the myxospore stage of Ceratomyxa shasta, as infected fish were more readily available compared with infected polychaetes (the latter were only available later in the study). This base assay was then modified and a sampling and filtration protocol developed to detect infective stages in river water samples. Use of a filter membrane allowed concentration of spores from a water sample and reduced inhibition effects. The final filtration method was portable and required only a flat surface on which to work, a source of electricity to power the vacuum pump, and non-river water to rinse the filtration apparatus. This enabled water samples to be reduced to fit into microfuge tubes in the field.

Several studies have reported inhibition of QPCRs associated with environmental water samples (e.g. Brinkman et al. 2003, Guy et al. 2003). Inhibitory compounds may include phenols, humic acids and heavy metals (Wilson 1997). To overcome this issue, researchers have modified the extraction/purification 
process and/or the QPCR mix. BSA (20 to $250 \mathrm{ng} \mathrm{ul}^{-1}$ ) is a common addition to the QPCR mix (e.g. Bowers et al. 2000, Brinkman et al. 2003), and has been found to reduce inhibition (Guy et al. 2003). Brinkman et al. (2003) found the added step of purification provided by a kit or dilution of the DNA samples was necessary (BSA at $250 \mathrm{ng}^{-1} \mathrm{l}^{-1}$ was already a standard reagent in their QPCR mix).

We encountered varying degrees of inhibition at different field sites, as determined by comparison of spiked river water versus MG water. BSA was a crucial reagent for success of these assays. Concentrations up to $250 \mathrm{ng}^{-1} \mathrm{l}^{-1}$ improved QPCR performance, but higher concentrations (500 $\mathrm{ng}^{-1} \mathrm{l}^{-1}$ ) had no additional benefit. Comparison of $\mathrm{Ct}$ values of spiked MG water with and without BSA demonstrated that addition of BSA had no adverse effect on the assay. The template volume ( $\mu$ l of extracted DNA) was also determined to be important to the success of the reaction. The higher the volume, the higher the inhibition, and BSA was less effective at these higher volumes. We determined that $1 \mu \mathrm{l}$ of template (of an initial 11 sample eluted into $120 \mu \mathrm{l}$ ) in combination with $250 \mathrm{ng}^{-1} \mathrm{l}^{-1} \mathrm{BSA}$ reduced inhibition dramatically. However, if inhibition remained high, a second purification of the sample was required. We spiked all environmental water samples and compared them with spiked MG water: those that had a Ct value similar to MG water were deemed free of inhibitors, those with a greater $\mathrm{Ct}$ value were considered inhibited and were re-purified and re-assayed.

In a QPCR assay, individual reactions are quantified by their threshold cycle value $(\mathrm{Ct})$ which represents the cycle number at which the amplified product emits sufficient fluorescence to cross a nominated threshold. $\mathrm{Ct}$ allows comparison of samples within and across assays. A standard curve is constructed from the values of samples containing a known amount of target template DNA, and unknown samples subjected to the same QPCR conditions can then be correlated against the curve and the starting amount of DNA determined. We generated standard curves with high correlation coefficients for quantitative serial dilutions of synthetic template of known DNA concentration and copy number and for multiple samples of known numbers of extracted whole spores (not serially diluted). Comparison of $\mathrm{Ct}$ values for extracted and non-extracted spores and for those processed with and without a filter paper indicated that DNA was lost in the extraction process, to the greatest degree with inclusion of a filter membrane. Thus, both test and standard samples must be processed (extraction through to QPCR) similarly for a standard curve to be valid.

Both life stages (actinospore and myxospore) of myxozoan parasites have the same genetic makeup (18S rDNA gene) (see Andree et al. 1997, Bartholomew et al. 1997), hence the same molecular methods can be used to detect parasite stages in both the invertebrate and vertebrate hosts and in the aquatic environment. This similarity, therefore, does not permit distinction of the fish-infecting stage (actinospore) from the worminfecting stage (myxospore) using 18S rDNA methods: detection by QPCR could be due to the presence of either spore type.

QPCR methodology has been applied to 1 other myxozoan, Myxobolus cerebralis, for detection of infection in fish (Cavender et al. 2004, Kelley et al. 2004). There is an implicit assumption that the same number of copies of the gene per nucleus is present in all parasite stages. Kelley et al. (2004) determined that each $M$. cerebralis cell (presumably each nucleus) had 104 copies of the $18 \mathrm{~S}$ rDNA gene. The infective stage to fish, the triactinomyxon spore, is comprised of 71 cells or nuclei ( 3 valve cells, 3 capsulogenic cells, 64 germ cells and 1 sporoplasm enveloping cell; see El-Matbouli \& Hoffmann 1998) which equates to 7384 copies per spore, while the worm-infective stage, the myxobolus spore, has only 5 cells (but 6 nuclei; see ElMatbouli et al. 1995) and thus has only 624 copies of the gene; a 10-fold difference in copy numbers between the 2 stages.

Fortunately, this is not the case for Ceratomyxa shasta: the myxospore contains 5 cells and 6 nuclei $(2$ valve cells, 2 polar capsules, and a binucleate sporoplasm) and the actinospore has 7 cells and 7 nuclei ( 3 valve cells, 3 capsulogenic cells, and a uninucleate sporoplasm) (Bartholomew et al. 1997). This similarity means that either stage, both of which may be isolated from river water samples, would be equally represented in the QPCR assay. Palenzuela et al. (1999) could detect as low as 1/100th of a spore from C. shasta seeded fish tissue in their PCR assay and thus determined that there were at least 100 copies of the rDNA gene per myxospore. QPCR methodology is more sensitive, and we determined about 100000 copies per spore, equating to $\sim 16700$ copies per nucleus.

There is limited documentation of other myxozoans present in Klamath River and which may have been present in our water samples. Parvicapsula minibicornis infects Chinook salmon (J. S. Foott pers. comm.), and Facieplatycauda pratti and Myxobolus kozloffi have been described from the Klamath Lake sucker Catostomus luxatus from the Williamson River (Wyatt 1979). Additionally, we identified a Chloromyxum sp., a Myxidium sp. and a Zschokkella sp. in the sentinel rainbow trout Oncorhynchus mykiss, and a Myxobolus sp. in the fathead minnow Pimephales promelas (unpubl. data). Of these myxozoans, 18S rDNA sequence data was available only for Parvicapsula minibicornis, and was consulted during the primer/probe combination design and selection pro- 
cess. A BLAST search of the primers and probe showed no match with any other organism. An extra degree of specificity was provided by the use of TaqMan chemistry, which includes a third targeted oligonucleotide sequence-the probe-over SYBR Green (which detects any double stranded DNA generated during the PCR). None of the non-Ceratomyxa shasta myxozoans we collected from Klamath fishes fluoresced in the QPCR assay.

The utility of this assay as a rapid method for determining parasite abundance in water was tested in the Klamath River system, where Ceratomyxa shasta is enzootic (Hendrickson et al. 1989). The Klamath River begins in South Central Oregon and enters the Pacific Ocean in Northern California. From the upper end of Klamath Lake, the river is approximately 423 river kilometres ( $\mathrm{Rkm}$ ) long, with a series of 5 dams creating a sequence of reservoirs interrupted by free-flowing reaches in the upper portion of the river. Assays of water sampled along the river and from several tributaries demonstrated that $C$. shasta occurred throughout the Klamath River, but that its abundance fluctuated. This was consistent with data from a concurrent sentinel fish study (Stocking et al. 2006). At the most upriver site, where the Williamson River enters Klamath Lake, Ct values were relatively low (30), representing high densities of approximately 10 to 20 spores $\mathrm{l}^{-1}$. Although sentinel fish were not recovered from this site when the water was sampled, exposures at other times have consistently resulted in high mortality from C. shasta (authors' unpubl. data). This initial high spore content is apparently diluted after it enters Klamath Lake (Ct 39; <1 spore $\mathrm{l}^{-1}$ ). Between Klamath lake and Iron Gate dam (the lowest dam at Rkm 307) abundance of $C$. shasta fluctuated, with $\mathrm{Ct}$ values of reservoir samples above $38\left(<1\right.$ parasite $\left.\mathrm{l}^{-1}\right)$ and Ct values from free-flowing river sites ranging from 32 to 41 (<1 to 5 spores $\mathrm{l}^{-1}$ ). Mortality as a result of C. shasta was less than $10 \%$ at all locations from Klamath Lake to Iron Gate dam, although fish became infected. High C. shasta densities were again detected from 2 mainstem Klamath River sites below Iron Gate dam: Beaver Creek (Rkm 259) and Green Riffle (Rkm 113). Here, Ct values averaged 29 (>20 spores $\mathrm{l}^{-1}$ ) and 32 (5 spores $\left.\mathrm{l}^{-1}\right)$, respectively. While mortality at all locations below the dams was greater than $95 \%, \mathrm{Ct}$ values at sites lower in the river (Rkm 81 and 8) were higher (avg. 34 and 36, respectively), suggesting that point sources for C. shasta were further upriver. Although QPCR values obtained from a single 11 sample could not be directly correlated with infection severity in fish, infection was detected in fish at all but 1 site, where C. shasta was detected by QPCR. QPCR levels were not an accurate predictor of percent mortality, probably because of the small sample size. However, it would be expected that values that translate to greater than 10 spores $\mathrm{l}^{-1}$ would represent sites of high infectivity.

Tributaries were not point sources of Ceratomyxa shasta, as reflected by the inability to detect the parasite by QPCR or sentinel fish. One exception to this was Hunter Creek, where a single fish died, yet $\mathrm{Ct}$ values (avg. 35) reflected a parasite density of $\sim 1$ spore $1^{-1}$. This may reflect a predominance of myxospore stages at this location, as the assay detects all stages of $C$. shasta whereas the fish 'detect' only the actinospore stage. Although myxospores would most likely be detected in autumn, as adult salmon return to spawn, infected juveniles could account for myxospore release at other times.

To gauge the variability of Ceratomyxa shasta spore density at a location over time, water samples were collected over $10 \mathrm{~h}$ from 2 sites with different temperature, flow and infection characteristics. A temporal pattern was evident at the upriver site, Bypass Reach (J. C. Boyle), where parasite abundance increased 10fold ( $<1$ to 10 spores $\mathrm{l}^{-1}$ ) over a $6 \mathrm{~h}$ period from 10:10 to 16:10 h. This directly corresponded with water temperature, which also increased from 13.8 to $15.6^{\circ} \mathrm{C}$ from the start of sampling to 16:10 h. A drop in river level was also noted at this time, suggesting that increased parasite concentrations may correspond with decreased water flow. A correlation between temperature and parasite level was not observed at the downriver site, Beaver Creek, where water temperatures were higher $\left(20\right.$ to $22^{\circ} \mathrm{C}$ ). Spore densities were consistently high over this period and ranged from 10 to $>20$ spores $\mathrm{l}^{-1}$, and the water level did not vary.

The variations in spore density at the Boyle Bypass site may explain the apparent discrepancy between the relatively low $\mathrm{Ct}$ value we obtained from the sample taken concurrent with the sentinel fish exposure, and the lower than expected mortality in the exposure group: an indication that we need to be cautious when extrapolating data at sites where water flows fluctuate. The sentinel fish and water sample data is not fully comparable, since the QPCR detects both stages of the parasite whereas the sentinel study detects only the actinospore. Furthermore, the QPCR used 11 of water collected at one point in time whereas fish in the sentinel studies were exposed to many litres of water over $4 \mathrm{~d}$.

A distinct advantage of the QPCR methodology is the greatly reduced time required to determine the presence of the parasite in river water compared with sentinel fish exposures and elimination of the burden of holding fish in the laboratory until clinical signs develop. The shortfall of QPCR methodology is its inability to discriminate between the fish- and polychaete-infective stages of Ceratomyxa shasta, and hence the detected parasite load in the water samples 
may comprise any ratio of these. Further, only a small volume of the river is sampled and at a single timepoint, compared with sentinel fish which 'sample' river water throughout the duration of exposure. We have already determined that spore abundance at a site may vary over the course of a day and, therefore, before the QPCR method can replace sentinel exposures, the variability in spore abundance at a site at different vertical and horizontal transects of the river also needs to be assessed to determine the most representative sampling regime.

Acknowledgements. Informative conversations with K. True (Ca-Nv Fish Health Center), and M. Powell (University of Idaho) were appreciated. M. Dasenko (OSU) provided training on the ABI PRISM 7000 system. We are grateful to S. D. Atkinson (OSU) for assistance with processing water samples, his steady hand pipetting individual spores into QPCR tubes and onto filter membranes and critical review of the manuscript. R. W. Stocking, H. V. Lorz, D. G. Stevens, R. A. Holt, S. D. Atkinson, M. Hiner and J. S. Foott assisted with water sample collection along the Klamath River. This publication was partially supported by the National Sea Grant College Program of the US Department of Commerce's National Oceanic and Atmospheric Administration under NOAA Grant No. NA16RG1039 (project number R/RCF-15) and by appropriations made by the Oregon State legislature. Additional funding was provided by PacifiCorp (Portland, Oregon) FERC project number 2082 and the Karuk Department of Natural Resources. The views expressed herein do not necessarily reflect the views of any of those organisations.

\section{LITERATURE CITED}

Altschul SF, Madden TL, Schäffer AA, Zhang J, Zhang Z, Miller W, Lipman DJ (1997) Gapped BLAST and PSIBLAST: a new generation of protein database search programs. Nucleic Acids Res 25:3389-3402

Andree KB, Gresoviac SJ, Hedrick RP (1997) Small subunit ribosomal RNA sequences unite alternate actinosporean and myxosporean stages of Myxobolus cerebralis the causative agent of whirling disease in salmonid fish. J Eukaryot Microbiol 44:208-215

Bartholomew JL, Whipple MJ, Stevens DG, Fryer JL (1997) The life cycle of Ceratomyxa shasta, a myxosporean parasite of salmonids, requires a freshwater polychaete as an alternate host. J Parasitol 83:859-868

Bartholomew JL, Rohovec JS, Fryer JL (1989a) Development, characterization, and use of monoclonal and polyclonal antibodies against the myxosporean, Ceratomyxa shasta. J Protozool 36:397-401

Bartholomew JL, Smith CE, Rohovec JS, Fryer JL (1989b) Characterization of a host response to the myxosporean parasite, Ceratomyxa shasta (Noble), by histology, scanning electron microscopy and immunological techniques. J Fish Dis 12:509-522

Bartholomew JL, Ray E, Torell B, Whipple MJ, Heidel JR (2004) Monitoring Ceratomyxa shasta infection during a hatchery rearing cycle: comparison of molecular, serological and histological methods. Dis Aquat Org 62:85-92
Bowers HA, Tengs T, Glasgow HB Jr, Burkholder JM, Rublee PA, Oldach DW (2000) Development of real-time PCR assays for rapid detection of Pfiesteria piscicida and related dinoflagellates. Appl Environ Microbiol 66: 4641-4648

Brinkman NE, Haugland RA, Wymer LJ, Byappanahalli M, Whitman RL, Vesper SJ (2003) Evaluation of a rapid, quantitative real-time PCR method for enumeration of pathogenic Candida cells in water. Appl Environ Microbiol 69:1775-1782

Cavender WP, Wood JS, Powell MS, Overturf K, Cain KD (2004) Real-time quantitative polymerase chain reaction (QPCR) to identify Myxobolus cerebralis in rainbow trout Oncorhynchus mykiss. Dis Aquat Org 60:205-213

El-Matbouli M, Hoffmann RW (1998) Light and electron microscopic studies on the chronological development of Myxobolus cerebralis to the actinosporean stage in Tubifex tubifex. Int J Parasitol 28:195-217

El-Matbouli M, Hoffmann RW, Mandok C (1995) Light and electron microscopic observations on the route of the triactinomyxon-sporoplasm of Myxobolus cerebralis from epidermis into rainbow trout cartilage. J Fish Biol 46: 919-935

Fontaine M, Guillot E (2003) An immunomagnetic separationreal-time PCR method for quantification of Cryptosporidium parvum in water samples. J Microbiol Methods 54: 29-36

Foott JS, Harmon R, Stone R (2003) FY2002 Investigational report: ceratomyxosis resistance in juvenile chinook salmon and steelhead trout from the Klamath River. USFWS, California-Nevada Fish Health Center, Anderson, CA

Fox M, Palenzuela O, Bartholomew JL (2000) Strategies for the diagnosis of Ceratomyxa shasta using the polymerase chain reaction: comparison of lethal and non-lethal sampling with microscopic examination. J Aquat Anim Health 12:100-106

Guy RA, Payment P, Krull UJ, Horgen PA (2003) Real-time PCR for quantification of Giardia and Cryptosporidium in environmental water samples and sewage. Appl Environ Microbiol 69:5178-5185

Hendrickson GL, Carlton A, Manzer D (1989) Geographic and seasonal distribution of the infective stage of Ceratomyxa shasta (Myxozoa) in Northern California. Dis Aquat Org 7:165-169

Kelley GO, Francisco J, Vergara Z, Leutenegger CM and 7 others (2004) Evaluation of five diagnostic methods for the detection and quantification of Myxobolus cerebralis. J Vet Diagn Investig 16:195-204

Le Cann P, Ranarijaona S, Monpoeho S, Le Guyader F, Ferre V (2004) Quantification of human astroviruses in sewage using real-time RT-PCR. Res Microbiol 155:11-15

Palenzeula O, Trobridge G, Bartholomew JL (1999) Development of a polymerase chain reaction diagnostic assay for Ceratomyxa shasta, a myxopsorean parasite of salmonid fish. Dis Aquat Org 36:45-51

Stocking RW, Holt RA, Foott JS, Bartholomew JL (2006) Spatial and temporal occurrence of the salmonid parasite Ceratomyxa shasta in the Oregon-California Klamath River Basin. J Aquat Anim Health 18:in press

Wilson IG (1997) Inhibition and facilitation of nucleic acid amplification. Appl Environ Microbiol 63:3741-3751

Wyatt EJ (1979) Facieplatycauda ratti gen. n., sp. N. and two new species of Myxobolus (Myxosporida). J Protozool $26: 47-51$

Submitted: September 30, 2005; Accepted: December 13, 2005 Proofs received from author(s): July 11, 2006 